\title{
The Long-Term Earthquake Prediction for the Kuril-Kamchatka Island Arc for the April 2016 through March 2021 Period, its Modification and Application; the Kuril-Kamchatka Seismicity before and after the May 24, 2013, M 8.3 Deep-Focus Earthquake in the Sea of Okhotsk
}

\author{
S. A. Fedotov ${ }^{a, b}$, * and A. V. Solomatin ${ }^{a, * *}$ \\ ${ }^{a}$ Institute of Volcanology, Far East Branch, Russian Academy of Sciences, \\ bul'var Piipa 9, Petropavlovsk-Kamchatskii, 683006 Russia \\ ${ }^{b}$ Institute of Physics of the Earth, Russian Academy of Sciences, \\ ul. Bol'shaya Gruzinskaya 10, str. 1, Moscow, 123810 Russia \\ *e-mail: karetn@list.ru \\ **e-mail: alf55@mail.ru \\ Received July 5, 2016
}

\begin{abstract}
This paper discusses results from ongoing research on long-term earthquake prediction for the Kuril-Kamchatka island arc based on the concepts of seismic gaps and the seismic cycle. We developed a forecast for the next 5 years (April 2016 through March 2021) for all segments of the earthquake-generating zone along the Kuril-Kamchatka arc. The 20 segments of the arc were analyzed to develop forecasts of the appropriate phases of the seismic cycle, a normalized parameter of the rate of small earthquakes $\left(\mathrm{A}_{10}\right)$, the magnitudes of moderate earthquakes that are expected with probabilities of $0.8,0.5$, and 0.15 , the maximum expected magnitudes, and the probabilities of great $(M \geq 7.7)$ earthquakes. We discuss the seismic process in the Kuril-Kamchatka earthquake-generating zone before and after the deep-focus May 24, 2013 M 8.3 earthquake in the Sea of Okhotsk. The results corroborate the high seismic hazard in the area of Petropavlovsk-Kamchatskii and the urgent need for continuing with and expanding the ongoing work of seismic retrofitting and seismic safety enhancement. We quote practical results from applications of the method during 30 years.
\end{abstract}

DOI: $10.1134 / \mathrm{S} 0742046317030022$

\section{INTRODUCTION. THE PRINCIPLES OF THE LONG-TERM EARTHQUAKE PREDICTION METHOD \\ FOR THE KURIL-KAMCHATKA ARC AND THE PREDICTED QUANTITIES}

The Kuril-Kamchatka island arc, the Kuril Islands, and eastern Kamchatka are the areas of the highest seismicity in Russia, where the earthquake hazard problem is one of national significance. The ongoing earthquake prediction work of the Institute of Volcanology and Seismology, Far East Branch, Russian Academy of Sciences (IV\&S FEB RAS), including the long-term earthquake prediction (LTEP) research for the Kuril-Kamchatka region that has been conducted since 1965, are an important part of the effort.

The principles of the LTEP method as used in the present study, the patterns on which it is based, the properties and parameters of seismicity, the theory behind the method, as well as the ways and means of developing forecasts can be found in (Fedotov, 1965, 1968, 2005; Fedotov et al., 1980, 2004; Fedotov and Solomatin, 2015, among many others). Below we provide information that is needed for understanding the principles on which the forecasts were based and the results that have been achieved with the LTEP method.

The long-term 5-year forecasts of earthquake hazard for the Kuril-Kamchatka arc are developed by the LTEP method once every 6 months. The forecasts are registered at the joint Council of the Institute of Volcanology and Seismology FEB RAS and of the Kamchatka Branch of the United Geophysical Service (KB UGS) of the Russian Academy of Sciences (RAS), which discusses prediction of earthquakes and volcanic eruptions and, along with other forecasts, sends weekly notices to the authorities and interested organizations.

The forecasts are updated at shorter intervals if large earthquakes are occurring in the Kuril-Kam- 
chatka earthquake-generating zone or in adjacent regions or if the parameters of the seismic process have changed substantially. In that case the changes are studied in a comprehensive manner to update the existing seismic hazard.

Forecasts are based on the seismicity parameter values for the preceding 5 years. The basic parameter set includes:

- Seismic activity $\mathrm{A}_{10}\left(1 / \mathrm{yr} 10^{3} \mathrm{~km}^{2}\right)$, which is a normalized rate of earthquakes with energy class $\mathrm{K}_{\mathrm{S}}=$ $10, M=3.6$ (Fedotov, 1968, 2005; among others); the "seismic activity" concept was defined earlier by Yu.V. Riznichenko (Riznichenko, 1968; among others);

- The relative release of seismic energy $\mathrm{D}=\mathrm{E}_{2} / \mathrm{E}_{1}$, where $\mathrm{E}_{2}\left(\mathrm{~J} / \mathrm{yr} 10^{3} \mathrm{~km}^{2}\right)$ is the current normalized seismic energy within an area of study; $\mathrm{E}_{1}=8.82 \times$ $10^{13}\left(\mathrm{~J} / \mathrm{yr} 10^{3} \mathrm{~km}^{2}\right)$ is a similar quantity that gives an average value for the entire Kuril-Kamchatka earthquake-generating zone in the segment of its highest activity for the entire period of observation ${ }^{1}$ (Fedotov, 1968, 2005; among others);

- The parameter $A_{11}\left(1 / \mathrm{yr} \times 10^{3} \mathrm{~km}^{2}\right)$ is similar to $\mathrm{A}_{10}$, but is based on the mean annual number of moderate earthquakes $\left(\mathrm{K}_{\mathrm{S}} \sim 11-12, \mathrm{M} \sim 4-5\right)$ for a longer period (10-15 years); to make this parameter comparable with $A_{10}$ we extrapolated the values to $K_{S}=10$ incorporating corrections that are functions of the $b$ value, as well as regional corrections (Fedotov et al., 2008; among others).

The forecasts are based on the concept of a cyclic evolution of seismicity in the rupture zones of great $(\mathrm{M} \geq 7.7)$ earthquakes, with the cycle duration being $140 \pm 60$ years or $120 \pm 50$ years (Fedotov, 1968, 2005). The entire cycle divides into three main phases: phase I, which is the phase of aftershock processes (lasting 15-20 years); phase II, which is a long phase where elastic energy is being steadily stored $(65-110$ or more years); and phase III, which is the terminal phase (shorter than 15-20 years), which involves a buildup of considerable amounts of energy, a highly unstable seismic process, seismicity increases, and quiescences, as well as foreshocks.

Long-term forecasts are developed for the most active band of the Kuril-Kamchatka earthquake-generating zone $100 \mathrm{~km}$ wide with depths of focus of $0-80 \mathrm{~km}$. It is beneath the continental slope of the deep-sea trench of this island arc where over $85 \%$ of all KurilKamchatka earthquakes occur and where the hypocenters of all those earthquakes are which can cause shaking over intensity VIII on the Kuril Islands and in the eastern coast of Kamchatka.

\footnotetext{
${ }^{1}$ The parameters $\mathrm{E}$ and $\mathrm{D}$ are based on the following relations between seismic energy, energy class, and magnitude: $\mathrm{K}_{\mathrm{S}}=\log E(\mathrm{~J})$; $\mathrm{K}_{\mathrm{S}}=1.5 \mathrm{M}+4.6 ; \mathrm{M}=\mathrm{M}_{\mathrm{LH}}=\mathrm{M}_{\mathrm{S}}=\mathrm{M}_{\mathrm{W}}$ (Fedotov et al., 2008). Earthquake energy class $\mathrm{K}_{\mathrm{S}}$ is found from the scale given by Fedotov (1972).
}

The prediction band of the Kuril-Kamchatka island arc is divided into 20 segments 100 to $200 \mathrm{~km}$ long; these are comparable in size with the rupture zones of great earthquakes (Fig. 1). For these we predict several seismicity characteristics, with the main ones being the phases of the seismic cycle, a normalized characteristic of the rate of small earthquakes $\left(\mathrm{A}_{10}\right)$, magnitudes of moderate earthquakes that are expected with probabilities $0.8,0.5$, and 0.15 , the maximum expected magnitudes, and the probabilities of the occurrence of great earthquakes $(M \geq 7.7)$.

The first characteristic to be predicted for each of the segments and groups of them is the phase of the seismic cycle that the segment is currently in. The most likely areas of future great $(M \geq 7.7)$ earthquakes in accordance with the patterns we use in the evolution of seismicity are seismic gaps, that is, segments where no such earthquakes have occurred during the last 80 years, and which may be in phase III, the terminal phase. For such segments we indicate the maximum expected magnitudes $\mathbf{M}_{\max }$ of great earthquakes in these segments and the conditional probability for such earthquakes to occur during the next 5 years $\mathrm{P}(\mathrm{M} \geq 7.7)$.

The first value of the quantity $\mathrm{P}(\mathrm{M} \geq 7.7)$ consists in the fact that it is an estimate of the occurrence probability of the next great earthquake for the segment in question in the region. At the same time it is an approximate estimate for the occurrence of such an earthquake in this segment during the next 5 years, because the average rate of great earthquakes in the Kuril-Kamchatka arc is once every 5 years. Thus, the sum of $\mathrm{P}(\mathrm{M} \geq 7.7)$ in all segments is assumed to be $100 \%$ for our construction of 5-year forecasts (Fedotov, 2005; Fedotov et al., 2007, 2008, 2011, 2012; Fedotov and Solomatin, 2015).

The earthquake hazard of segments that are currently in the terminal (III) phase of the seismic cycle, or seismic gaps, as reflected in the estimate of the probability $\mathrm{P}(\mathrm{M} \geq 7.7)$, is determined by the degree of activity for the seismic processes observed in them. As was shown in (Fedotov, 1968, 2005; Fedotov et al., 1980, 2008, 2012; among others), this increase of activity is characteristic for the terminal phase in the evolution of rupture zones of great earthquakes.

The probabilistic estimate of $\mathrm{P}(\mathrm{M} \geq 7.7)$ is constructed for each of the seismic gaps based on estimates of probability for random occurrence of the values of $A_{10}, D, A_{11}$ in them during phase II (the quiet period) of the seismic cycle: $\mathrm{P}\left(\mathrm{A}_{10}\right), \mathrm{P}(\mathrm{D})$, and $\mathrm{P}\left(\mathrm{A}_{11}\right)$ (Fedotov et al., 1980, 2008): $\mathrm{B}\left(\mathrm{A}_{10}, \mathrm{D}\right)=\mathrm{P}\left(\mathrm{A}_{10}\right) \times \mathrm{P}(\mathrm{D})$, $\mathrm{B}_{1}\left(\mathrm{~A}_{10}, \mathrm{D}, \mathrm{A}_{11}\right)=\mathrm{P}\left(\mathrm{A}_{10}\right) \times \mathrm{P}(\mathrm{D}) \times \mathrm{P}\left(\mathrm{A}_{11}\right)$, or $\mathrm{B}_{2}\left(\mathrm{~A}_{10}\right.$, $\left.\mathrm{D}, \mathrm{A}_{11}\right)=\left(\mathrm{P}\left(\mathrm{A}_{10}\right)+\mathrm{P}(\mathrm{D})+\mathrm{P}\left(\mathrm{A}_{11}\right)\right) / 3$. The predicted value of $P(M \geq 7.7)$ in a segment is assumed to be proportional to the value of (1-B) and to the length of the segment in question (Fedotov, 2005; Fedotov et al., 2011, 2012; among others). 


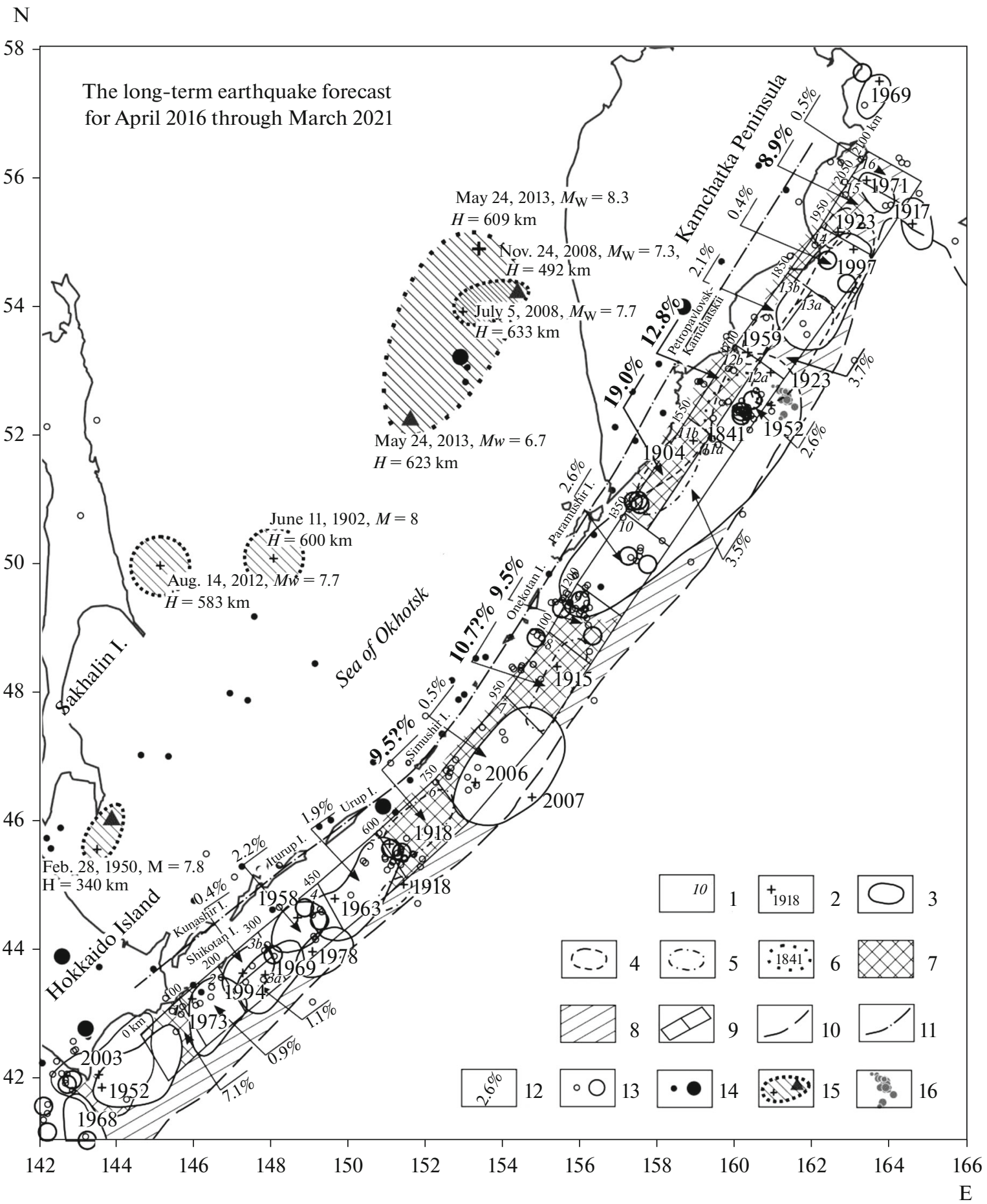

Fig. 1. A map of long-term earthquake forecast for the Kuril-Kamchatka arc showing the rupture zones of the $1902-2016 \mathrm{M} \geq$ 7.7 earthquakes and the probabilities of shallow $(\mathrm{H}<80 \mathrm{~km})$ earthquakes of this size in April 2016 through March 2021 in all segments of the prediction band.

(1) identification numbers of segments; (2) instrumental epicenters of $M \geq 7.7$ main shocks; (3) boundaries of $M \geq 7.7$ rupture zones with boundaries accurate to within $10 \mathrm{~km}$; (4) less accurate parts of the same boundaries; (5) likely rupture zones of the 1904-1918 M $\geq 7.7$ earthquakes; (6) a hypothetical rupture zone of the 1841 earthquake; (7) the most likely locations of next $M \geq$ 7.7 earthquakes; (8) possible locations of next earthquakes of this size; (9) boundaries of prediction segments; (10) trench axes; (11) the axis of the Kuril-Kamchatka volcanic belt; (12) the probabilities of $M \geq 7.7$ earthquakes for the April 2016 through March 2021 period, Table 1; (13) the epicenters of shallow earthquakes for the March 17, 2011 through April 16, 2016 period, smaller circles marking the $\mathrm{M}=5.0-5.9$ events, larger circles stand for $\mathrm{M}=6.0-7.4, \mathrm{H}<80 \mathrm{~km}$; (14) same for $\mathrm{H} \geq 80 \mathrm{~km}$; (15) the epicenters and rupture zones of deep-focus $(\mathrm{H}>300 \mathrm{~km})$ great earthquakes, the triangles marking their main aftershocks; (16) the March 4-19, 2011 earthquake swarm, $\mathbf{M}_{\max } \leq 5.2, \mathrm{H}<80 \mathrm{~km}$ (no. 9.3 in Table 2 and in Figs. 2 and 3). The mean probability of the $M \geq 7.7$ Kuril-Kamchatka earthquakes at a location during 5 years is $3.6-4.2 \%$. 
The segments that are at present in phases I and II of the seismic cycle pose a lower degree of hazard. For these too we indicate estimates of earthquake hazard $\mathrm{P}(\mathrm{M} \geq 7.7)$ based on the normal distribution for seismic cycle durations of $140 \pm 60$ years or $120 \pm 50$ years (Fedotov, 2005; among others).

In this way we successfully identify $2-3$ seismic gaps at the Kuril-Kamchatka arc (Fedotov et al., 2007, 2008, 2011, 2012; among others). The other parameters are also given in the forecasts (Fedotov, 2005; among others).

This paper has the following structure. The Introduction contains a description of the principles of the LTEP method. Section 1 gives a long-term earthquake forecast for the April 2016 through March 2021 period for the Kuril-Kamchatka arc based on the data available before April 2016. Section 2 is concerned with the features of the 2012-2016 seismicity related to the precursory process of the May 24, 2013 Sea-of-Okhotsk earthquake. The section also provides updates to the LTEP forecast. The Conclusions section summarizes the main results of long-term earthquake prediction work and its updates; it also discusses the practical significance and further applications of this method.

\section{A LONG-TERM EARTHQUAKE FORECAST FOR THE KURIL-KAMCHATKA ARC FOR THE APRIL 2016 THROUGH MARCH 2021 PERIOD (Based on the pre-April 2016 Estimates) ${ }^{2}$}

This forecast was developed by the LTEP method for the next 5 years, June 2016 through March 2021 as an update of the preceding forecast, which was for the September 2015 through August 2020 period. The raw data were taken from the regional catalogs of $\mathrm{KB}$ and SB UGS RAS (ftp://ftp.gsras.ru) for the preceding 5 years, March 2011 through March 2016. Our analysis of the seismic situation based on the occurrence of $M \geq 5$ earthquakes was based on the NEIC catalog (https://earthquake.usgs.gov/). The results are listed in Table 1 and in Fig. 1.

Figure 1 shows the basic prediction results for the upper part of the earthquake-generating zone at the Kuril-Kamchatka arc (at depths of $\mathrm{H} \leq 80 \mathrm{~km}$ ); this figure also shows the locations of the 20 segments of the most active band in the earthquake-generating zone for which we predict seismicity characteristics (see Table 1), as well as the likely locations of future $M \geq 7.7$ earthquakes in that zone, see the Introduction.

Table 1 is based on seismicity data for the preceding 5 years within each segment using estimates of $A_{10}, D$, and $\mathrm{A}_{11}$, Introduction. The assessments of predicted earthquake hazard in Table 1 were found on the basis of these three parameters. For comparison purposes

\footnotetext{
2 The forecast was registered April 21, 2016 at the Council of the IV\&S FEB RAS and KB UGS RAS on Prediction of Earthquakes and Volcanic Eruptions.
}

Table 1 also contains probabilities of $M \geq 7.7$ earthquakes and the relative hazards of the seismic gaps as obtained in the preceding long-term earthquake forecast for the September 2015 through August 2020 period. The probabilities $\mathrm{P}(\mathrm{M} \geq 7.7)$ in the seismic gaps are accurate to within $2-3 \%$.

\section{The Continuation of the Long-Term Earthquake}

Forecast for the Kuril-Kamchatka Arc for the April 2016 through March 2021 Period Developed by the Basic Method

The main results of the long-term earthquake forecast for the April 2016 through March 2021 period for all of the 20 segments that make up the most active part of the earthquake-generating zone on the Kuril Islands and in Kamchatka (see Fig. 1, Table 1) are as follows.

The most likely locations of future great $\mathrm{M} \geq 7.7$ earthquakes with depths of focus $\mathrm{H} \leq 80 \mathrm{~km}$ for the April 2016 through March 2021 period are again the segments around Petropavlovsk-Kamchatskii and in southern Kamchatka:

- For southern Kamchatka (segment 11b, see Fig. 1) the probability of an $\mathrm{M} \geq 7.7$ earthquake, $\mathrm{P}(\mathrm{M} \geq 7.7)$, that would produce shaking of intensity reaching VIII at Petropavlovsk-Kamchatskii is equal to $19.0 \%$;

- For the Avacha Bay (segment 12b, see Fig. 1) the probability of an $M \geq 7.7$ earthquake that could produce shaking of intensity reaching IX at Petropavlovsk-Kamchatskii is equal to $12.8 \%$.

The total probability for the occurrence of $\mathrm{M} \geq 7.7$ earthquakes that could produce shaking of intensity VIII-IX at Petropavlovsk-Kamchatskii during the future 5 years in the two segments of highest hazard, $11 \mathrm{~b}$ and $12 \mathrm{~b}$, which form an extensive seismic gap $350 \mathrm{~km}$ long, is equal to $31.8 \%$ (see Fig. 1, Table 1).

Earthquakes that could produce shaking of intensity VII-VIII at Petropavlovsk-Kamchatskii can also occur in segments 11a, 12a, 13a, and 13b, although the associated probabilities are lower, $11.9 \%$ (see Fig. 1, Table 1).

The total probability of $\mathrm{M} \geq 7.7$ earthquakes in segments $11 \mathrm{a}, 11 \mathrm{~b}, 12 \mathrm{a}, 12 \mathrm{~b}, 13 \mathrm{a}$, and $13 \mathrm{~b}$ that can produce shaking of intensity VII-IX at PetropavlovskKamchatskii can reach 43.7\% during the April 2016 through March 2021 period. To be more specific, the probability of intensity IX shaking at PetropavlovskKamchatskii during the period of time referred to above is equal to $12.8 \%$, while that for intensity VIII and VII shaking is $30.9 \%$ (see Table 1, Fig. 1).

According to the preceding forecast, which applies to the period September 2015 through August 2020, the probabilities of earthquakes that could produce shaking of intensities VII-IX, IX, and VII-VIII were $42.5 \%, 12.1 \%$, and $30.4 \%$, respectively. To sum up, the earthquake hazard for Petropavlovsk-Kamchatskii for the September 2015 through March 2016 period has 


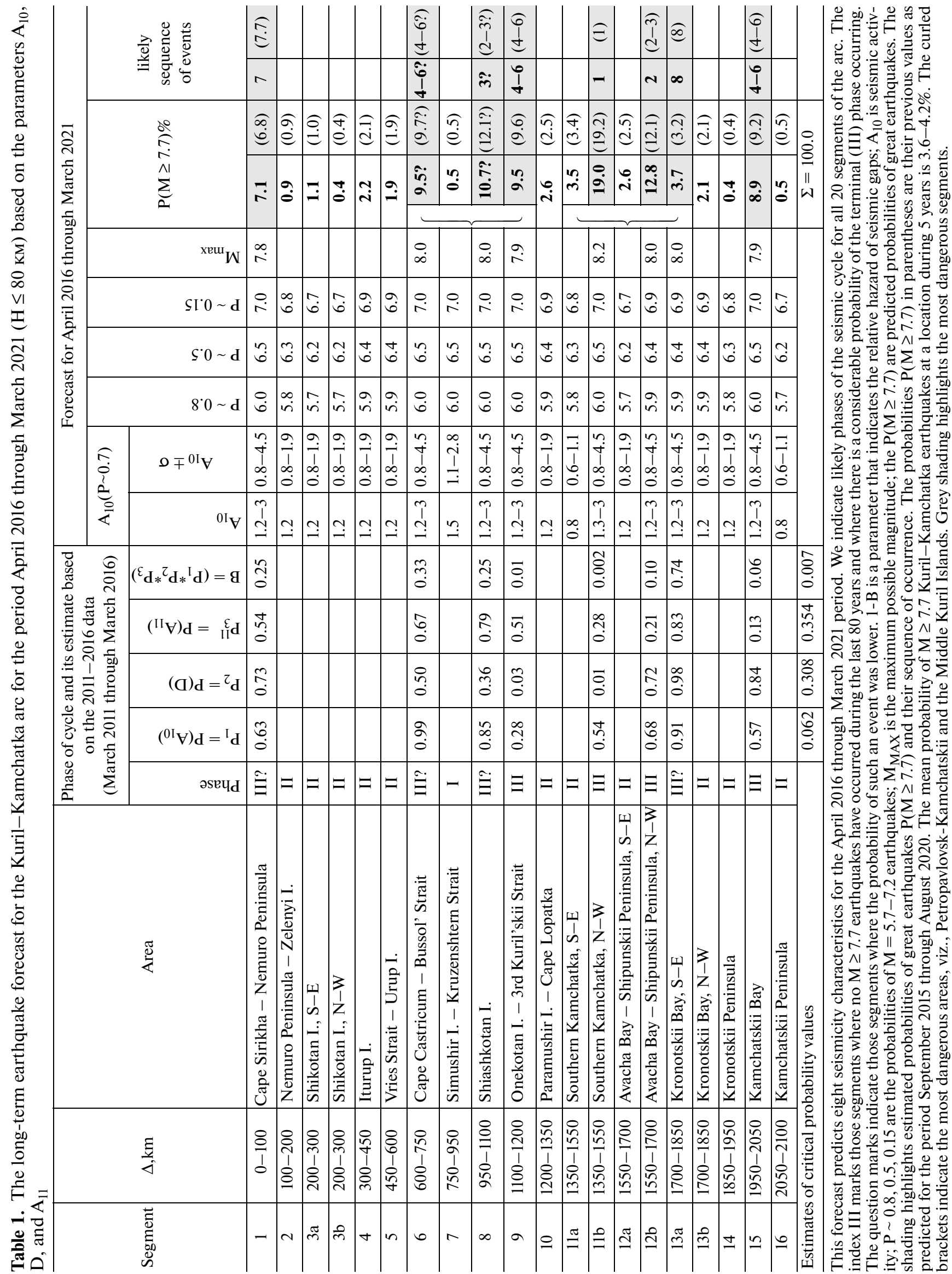


somewhat increased to within the determination uncertainty, and remains at a very high level. The hazard of intensity IX earthquakes at PetropavlovskKamchatskii is at present 3-4 times the average longterm hazard at the Kuril-Kamchatka earthquakegenerating zone, which is the greatest for all seismic regions in Russia.

Earthquake hazard is high in the Kamchatskii Bay area (segment 15, see Fig. 1, Table 1) where the probability of a great earthquake is estimated as $8.9 \%$ for the April 2016 through March 2021 period.

The area on the Kuril Islands where the earthquake hazard is the highest is the Middle Kuril Islands (segments 6, 8, and 9, see Fig. 1, Table 1). The total probability of a great $(M \geq 7.7)$ earthquake has not changed in this area, and is $29.7 \%$.

Segments 6 and 8 contain the ends of the mainshock rupture zones of the Middle-Kuril, or Simushir, M 8.2 earthquake of September 15, 2006 (Fedotov et al., 2007, 2008, 2011; among others) (see Fig. 1). It is also at this location that the highest activity for the entire Kuril island arc is observed. The probability of a great earthquake to occur in segment 8 during the April 2016 through March 2021 period is the third largest for the Kuril-Kamchatka arc, and is estimated as $10.7 ? \%$, with the respective values for segments 6 and 9 being $9.5 ? \%$ and $9.5 \%$. The question marks for segments 6 and 8 mean that the relevant seismicity levels may have been overestimated owing to the continuing influence of the aftershocks of the Middle-Kuril (Simushir) M 8.2 earthquake of November 15, 2006, as well as resulting from the response to the great deepfocus earthquake of August 14, 2012, $\mathrm{M}_{\mathrm{W}}=7.7$, $H=583 \mathrm{~km}$ (see Fig. 1).

The segment 1 off Nemuro Island (see Fig. 1, Table 1) is the seventh in the degree of hazard, $\mathrm{P}(\mathrm{M} \geq 7.7)=$ $7.1 \%$, for the April 2016 through March 2021 period.

The probability of great earthquakes $\mathrm{P}(\mathrm{M} \geq 7.7)$ in the other segments of the Kuril-Kamchatka earthquake-generating zone is equal to the average 5-year value, which is $3.6-4.2 \%$, or substantially below it, by factors of 10-15. Overall, the 5-year value of the probability, $\mathrm{P}_{7.7}=0.4-20 \%$, can vary by nearly two orders of magnitude in different segments of the Kuril-Kamchatka arc, depending on the particular phase of the seismic cycle and on the evolution of seismicity in the segments (see Fig. 1, Table 1).

\section{Additional Information on the Maxima of Seismic Activity $A_{10}$}

A detailed analysis of seismicity at the Kuril-Kamchatka arc during the January 2008 through March 2016 period was based on a map of isolines for the maximum values of seismic activity $\mathrm{A}_{10}$ with averaging applied to areas $50 \mathrm{~km}$ in diameter (Fig. 2). For this map we used the deviations of $\log \left(\mathrm{A}_{10}\right)$ from its long- term average in units of the standard deviation $\sigma\left(\log \left(A_{10}\right)\right.$ (Fedotov et al., 2008).

The maximum values of $\mathrm{A}_{10}$ were recorded in two areas at the boundary of the giant rupture zone of the 1952 Kamchatka earthquake $(M=8.5)$. The highest level of $A_{10}$ was observed near segment 12 at an extension of the line connecting the epicenter of the May 24, 2013 Sea-of-Okhotsk earthquake and the Avacha Bay (see Fig. 2). This maximum was largely due to the remote foreshock activity of May 18-24, 2013 that had been occurring there immediately before the earthquake.

A second area of abnormally high seismicity occurs in segment 9.

Overall, the two areas of abnormal seismicity indicated above adjoin the projection of the deep-focus Sea-of-Okhotsk earthquake onto the region of shallow earthquakes near the deep-sea trench, and are situated at the edges of the 1952 rupture zone (see Fig. 2). This fact, when combined with the exact coincidence between the time of the above seismicity increase and the occurrence of the deep-focus Sea-of-Okhotsk earthquake, seems to indicate a relationship between the respective geodynamic processes that are going on in the deeper and in the upper part of the earthquakegenerating zone, and to point to the locations of highstress regions in the upper part of the Kuril-Kamchatka earthquake-generating zone.

There are two more areas of high seismic activity during the 2008-2016 period, at the southwestern and the northeastern boundary of segment 6 ; the rupture zone of the preceding great deep-focus earthquake of August 14, $2012(\mathrm{M}=7.7)$ is projected onto these two areas (see Fig. 2).

There is thus some reason to think that the high seismic activity in all these four areas was were largely due to the influence of the rupture zones of the 20122013 Sea-of-Okhotsk earthquakes. It is these same areas which coincide with the boundaries of high-hazard seismic gaps as identified by the LTEP method, Figs. 1 and 2.

\section{THE EVOLUTION OF SEISMICITY AT THE KURIL-KAMCHATKA ARC BEFORE AND AFTER THE DEEP-FOCUS SEA-OF-OKHOTSK EARTHQUAKE OF MAY 24, 2013, M = 8.3}

\section{Local Seismicity Increases}

Section 1 was concerned with the distribution of low-magnitude $\left(\mathrm{K}_{\mathrm{S}} \sim 10-11\right)$ seismicity in the KurilKamchatka earthquake-generating zone. We determined the distribution using the parameter $\mathrm{A}_{10}$, which is seismic activity as averaged over a 5 -year period. Another important, and to some degree independent, characteristic of the seismic process consists in local seismicity increases, which are sets of earthquakes that 


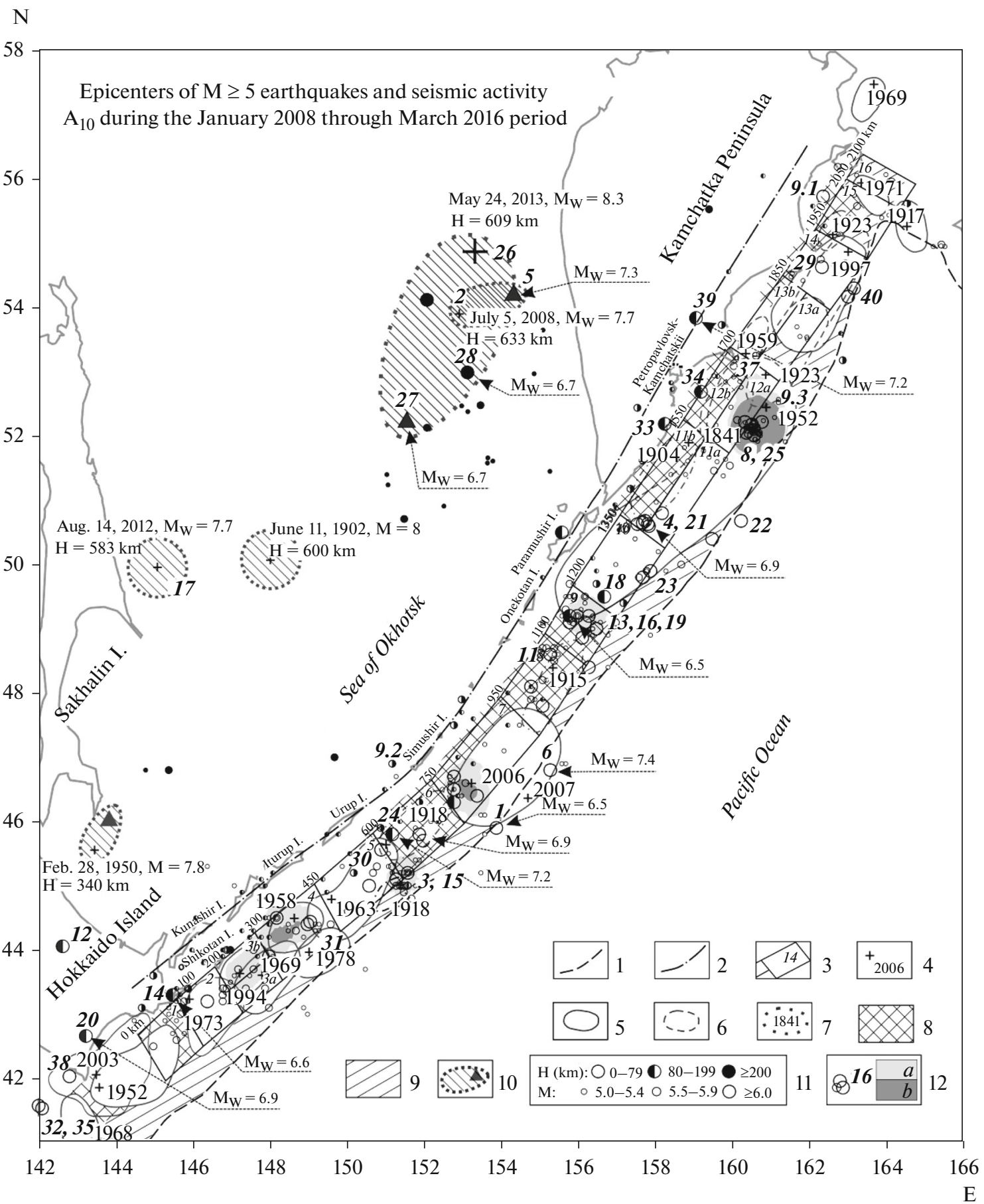

Fig. 2. A map of the Kuril-Kamchatka earthquake-generating zone with indication of prediction segments, the rupture zones of great $(M \geq 7.7)$ Kuril-Kamchatka earthquakes of 1841-2016, the epicenters of smaller $(M \geq 5)$ earthquakes that occurred in January 2008 through March 2016, and swarms of such earthquakes, as well as seismic activity $\mathrm{A}_{10}$ during those years at depths of 0 $80 \mathrm{~km}$.

(1) trench axes; (2) the axis of the Kuril-Kamchatka volcanic belt; (3) boundaries of prediction segments and their identification numbers; (4) instrumental epicenters of $M \geq 7.7$ main shocks; (5) boundaries of the rupture zones of shallow $(H<80 \mathrm{~km}) \mathrm{M} \geq$ 7.7 earthquakes to within $10 \mathrm{~km}$; (6) less accurate parts of the same boundaries; (7) likely rupture zones of the 1904-1918 shallow earthquakes and a hypothetical rupture zone of the $M \geq 7.71841$ event; (8) the most likely locations of next shallow $M \geq 7.7$ earthquakes; (9) possible rupture zones of next earthquakes of this size; (10) hypothetical boundaries of the rupture zones of $\mathrm{M} \geq 7.7$ earthquakes that occurred in 1902, 1950, 2008, 2012, and 2013, and their largest aftershocks; (11) the epicenters of smaller (M $\geq 5$ ) earthquakes that occurred during the January 2008 through March 2016 period as divided into classes of depth and magnitude; (12) the identification numbers of larger earthquakes and the seismicity increases that occurred during that period, Table $2 ; a, b$ levels of isolines of $\log \left(\mathrm{A}_{10}\right)$ that are equal to exceedance by one and two, respectively, standard deviations $\sigma\left(\log \left(\mathrm{A}_{10}\right)\right.$ above their long-term mean, for details consult main text. 


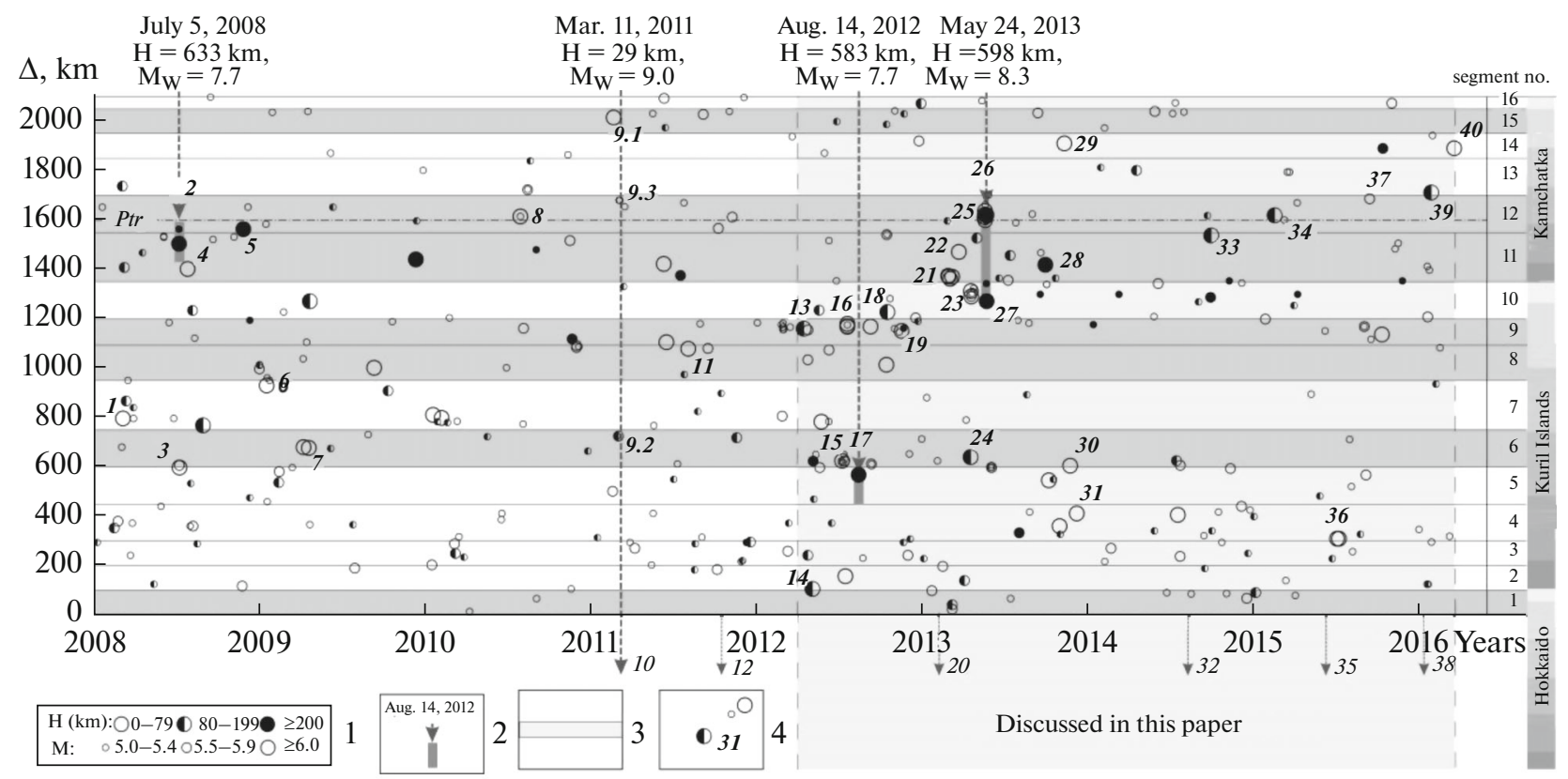

Fig. 3. A distance-time display of the seismic process along the Kuril-Kamchatka arc for the January 2008 through March 2016 period. The distance $\Delta \mathrm{km}$ is measured from the projections of earthquake epicenters onto the central line along the most active part of the earthquake-generating zone, segments $1-16$ in Figs. 1 and 2 and in Table 1.

(1) The distance-time projection of epicenters of the $M=5.0-7.4$ earthquakes that occurred during the period January 2008 through March 2016 as divided into classes of depth and magnitude; the projection is onto the axial line of the prediction band which runs along the most active part of the arc earthquake-generating zone, segments $1-16$ in Figs. 1 and 2 and in Tables 1 and 2; (2) same, for the rupture zones of the 2008, 2012, and 2013 great earthquakes, with indication of the date of the great Tohoku teleseismic event (see Fig. 2, Table 2); (3) the segments of the projection corresponding to the seismic gaps in segments of the Kuril-Kamchatka earthquake-generating zone (see Figs. 1 and 2, Table 1); (4) the numbering of the larger earthquakes in accordance with Table 2 . The values below the time axis are for events outside the prediction band, Fig. 2. Ptr stands for PetropavlovskKamchatskii.

are compact in space and time and which consist of discrete large earthquakes, their foreshocks and aftershocks, as well as earthquake swarms. These seismicity increases are responses of the earthquake-generating medium to external excitations, and indicate regions of higher stress concentration. Such increases occur during the phases of crack expansion and cracks tending to move closer to the plane of a future main shock as observed in laboratory experiments (Sobolev and Ponomarev, 2003). A method for identification of such seismicity increases was described by Fedotov and Solomatin (2015).

A number of remarkable great earthquakes occurred at the Kuril-Kamchatka arc, beneath the Sea of Okhotsk, as well as at an extension of the arc, in northeastern Japan, in 2008-2013. The seismicity of the Kamchatka segment of the arc for this period was discussed in the most general form in (Saltykov and Kravchenko, 2009, 2011; Saltykov et al., 2013; Chebrov et al., 2013, 2016; Sil'nye kamchatskie ..., 2014). The seismicity of the Kuril segment of the arc for the 2012-2013 period was studied by Safonov et al. (2015).

The 2008-2013 seismicity at the Kuril-Kamchatka arc was also studied by Fedotov and Solomatin (2015). Let us consider the later evolution of the seis- mic process within the Kuril-Kamchatka arc for the October 2013 through March 2016 period. Its important properties and features reveal the sequence and locations of $\mathrm{K}_{\mathrm{S}} \geq 14.0(\mathrm{M} \geq 6) \quad$ Kuril-Kamchatka earthquakes (Table 2). The present study is based on data for the Kuril-Kamchatka earthquakes inside and beyond the boundaries of the $100-\mathrm{km}$-wide prediction band that extends along the most active part of the earthquake-generating zone (Section 1) during the January 2008 through March 2016 period, including the data on deep earthquakes with $\mathrm{M}_{\mathrm{W}}=7.7-8.3$, as well as data on remarkable seismicity increases during that time period and on the most significant $\left(K_{S} \geq 14.0, M \geq 6\right)$ events in the entire range of hypocenter depths so far observed $(0-650 \mathrm{~km})$.

\section{The Spatio-Temporal Evolution} of Seismicity at the Arc in 2013-2016

We studied the time-dependent relationships between seismic events via a time-distance display of the seismic process (Fig. 3). Table 2 and Figs. 2 and 3 indicate a consistent numbering of the earthquakes.

The time-dependent display (Fig. 3) supplements the time coordinate (the horizontal axis) with distance 
Table 2. Earthquakes of energy class $\mathrm{K}_{\mathrm{S}} \geq 14.0\left(\mathrm{M}_{\mathrm{W}} \geq 6\right)$ and the most significant seismicity increases in the Kuril-Kamchatka region during the January 2008 through March 2016 period

\begin{tabular}{|c|c|c|c|c|c|c|}
\hline \multirow[t]{2}{*}{ Nos. } & \multirow{2}{*}{$\begin{array}{c}\text { Times of large } \\
\text { earthquakes } \\
\text { or of larger seismicity } \\
\text { increases }\end{array}$} & \multicolumn{3}{|c|}{$\begin{array}{l}\text { Coordinates of large } \\
\text { earthquakes or of larger } \\
\text { seismicity increases }\end{array}$} & \multirow[t]{2}{*}{$\begin{array}{c}\text { Time spans } \\
\text { of seismicity increases }\end{array}$} & \multirow{2}{*}{$\begin{array}{c}\text { Energy class } \mathrm{K}_{\mathrm{S}} \\
\text { (magnitude } \mathrm{Mw} \text { ) of large } \\
\text { earthquakes or of larger } \\
\text { seismicity increases }\end{array}$} \\
\hline & & ${ }^{\circ} \mathrm{N}$ & ${ }^{\circ} \mathrm{E}$ & $\mathrm{H}, \mathrm{km}$ & & \\
\hline 1 & Mar. 3, 2008 & 45.9 & 154.0 & 94 & Feb. 26-Mar. 8, 2008 & $14.0(6.5)$ \\
\hline 2 & July 5, 2008 & 53.9 & 152.9 & 633 & & (7.7) \\
\hline 3 & July 6, 2008 & 45.1 & 151.4 & 37 & July 6-16, 2008 & $14.5(5.7)$ \\
\hline 4 & July 24, 2008 & 50.8 & 158.3 & 36 & & $14.0(6.2)$ \\
\hline 5 & Sept. 24, 2008* & 54.2 & 154.3 & 492 & & $15.4(7.3)$ \\
\hline 6 & Jan. 15, 2009 & 46.8 & 155.4 & 41 & Dec. 28, 2008-Jan. 22, 2009 & $15.5(7.4)$ \\
\hline 7 & Apr. 7, 2009 & 45.8 & 152.0 & 68 & Apr. 7-24, 2009 & $14.8(6.9)$ \\
\hline 8 & July 30, 2010 & 52.2 & 160.5 & 38 & July $30-31,2010$ & $14.1(6.3)$ \\
\hline 9.1 & Feb. 20, 2011 & 55.7 & 162.5 & 48 & Feb. 20-Mar. 14, 2011 & $13.8(6.1)$ \\
\hline 9.2 & Mar. 3, 2011 & 46.9 & 151.3 & 154 & & $13.1(5.4)$ \\
\hline 9.3 & Mar. 5, 2011 & 52.5 & 161.3 & 48 & Feb. 28-27, 2011 & $12.3(5.2)$ \\
\hline $10 * *$ & Mar. 11, 2011 & 38.3 & 142.4 & 29 & & (9.0) \\
\hline 11 & Aug. 4, 2011 & 48.6 & 155.4 & 51 & & $14.1(6.0)$ \\
\hline 12 & Oct. 21,2011 & 44.0 & 142.7 & 175 & & $14.4(6.3)$ \\
\hline 13 & Apr. 14, 2012 & 49.2 & 155.9 & 90 & Apr. 13-24, 2012 & $14.0(5.6)$ \\
\hline 14 & May 4, 2012 & 43.3 & 145.6 & 92 & & $14.5(6.6)$ \\
\hline 15 & July 8, 2012 & 45.2 & 151.7 & 43 & July 4-17, 2012 & $14.0(6.0)$ \\
\hline 16 & July 20, 2012 & 49.1 & 156.3 & 43 & July $20-21,2012$ & $14.2(6.0)$ \\
\hline 17 & Aug. 14, 2012 & 49.6 & 145.5 & 587 & & (7.7) \\
\hline 18 & Oct. 16, 2012 & 49.5 & 156.8 & 87 & Oct. $14-22,2012$ & $14.0(5.6)$ \\
\hline 19 & Nov. 16, 2012 & 49.1 & 155.9 & 72 & & $14.9(6.5)$ \\
\hline 20 & Feb. 2, 2013 & 42.6 & 143.3 & 119 & Feb. 1-2, 2013 & $15.6(6.9)$ \\
\hline 21 & Feb. 28, 2013 & 50.7 & 157.9 & 47 & Feb. 28-Mar. 4, 2013 & $15.3(6.9)$ \\
\hline 22 & Mar. 24, 2013 & 50.7 & 160.4 & 42 & Mar. 24-Apr. 9, 2013 & $14.0(5.9)$ \\
\hline 23 & Apr. 19, 2013 & 49.9 & 157.8 & 60 & Apr. 19-25, 2013 & $14.1(6.1)$ \\
\hline 24 & Apr. 19, 2013 & 45.8 & 151.3 & 118 & Apr. 19-21, 2013 & $16.3(7.2)$ \\
\hline 25 & May 21, 2013 & 52.1 & 160.5 & 48 & May 18-24, 2013 & $14.4(6.1)$ \\
\hline 26 & May 24, 2013*** & 54.9 & 153.2 & 598 & & (8.3) \\
\hline 27 & May 24, 2013* & 52.1 & 151.8 & 642 & & $15.0(6.7)$ \\
\hline 28 & Oct. 1, 2013 & 53.0 & 153.3 & 605 & & $15.2(6.7)$ \\
\hline 29 & Nov. 12, 2013 & 54.6 & 162.5 & 72 & Nov. 12-13, 2013 & $15.0(6.4)$ \\
\hline 30 & Nov. 25, 2013 & 45.6 & 151.0 & 34 & & $13.6(6.0)$ \\
\hline 31 & July 20, 2014 & 44.4 & 149.1 & 75 & & $15.5(6.2)$ \\
\hline 32 & Aug. 10, 2014 & 41.6 & 142.0 & 42 & & $(6.1)$ \\
\hline 33 & Oct. 2, 2014 & 52.2 & 158.4 & 148 & & $14.0(5.7)$ \\
\hline 34 & Feb. 19, 2015 & 52.7 & 159.3 & 90 & & $13.8(5.4)$ \\
\hline 35 & June 8, 2015 & 41.6 & 142.0 & 42 & & (6.1) \\
\hline 36 & July 7, 2015 & 43.8 & 148.2 & 67 & July 5-11, 2015 & $15.4(6.3)$ \\
\hline 37 & Sept. 17, 2015 & 53.1 & 160.2 & 62 & & $13.3(5.4)$ \\
\hline 38 & Jan. 14, 2016 & 42.0 & 142.8 & 46 & & (6.7) \\
\hline 39 & Jan. 30, 2016 & 53.8 & 159.1 & 185 & Jan. 30-31, 2016 & $15.7(7.2)$ \\
\hline 40 & Mar. 20, 2016 & 54.2 & 163.1 & 61 & & $14.9(6.4)$ \\
\hline
\end{tabular}

* largest aftershocks; ** giant Tohoku earthquake off northeastern Japan. *** great Sea-of-Okhotsk earthquake. Boldface distinguishes the larger $(\mathrm{M} \sim 6.5-9)$ earthquakes. The epicenters are marked on the map of Fig. 2 and in the time-distance display (see Fig. 3).

$\Delta \mathrm{km}$, which is measured along the projection of earthquake epicenters onto the central line along the most active band of the earthquake-generating zone, segments 1 through 16 in Figs. 1 and 2 . Figure 3 highlights the earthquakes in the depth ranges $0-79,80-$ 199 , and $200-650 \mathrm{~km}$.
In the same manner as before, we studied the relationships between the most significant events under consideration and the most important seismic events in the region, which were the great deep-focus earthquakes of 2008-2013. This relationship between earthquakes as parts of the same seismic process may 
in large part be due to the block fragmentation of the Kuril-Kamchatka arc structure involving major transverse tectonic faults.

One good example of such a relationship is furnished by the evolution of the Urup series of shallow earthquakes in July 2012 through August 2013 (nos. 15 and 24, see Table 2) as discussed by Safonov et al. (2015); this series accompanied the occurrence of great deep-focus Sea-of-Okhotsk earthquakes: August 14, 2012, $\mathrm{M}=7.7$. and May 24, 2013, $\mathrm{M}=8.3$ (nos. 17 and 26 in Table 2, see Figs. 2 and 3).

Local seismicity can also be affected by large teleseismic events (Fedotov and Solomatin, 2015): the giant magnitude 9 Tohoku earthquake of March 11, 2011 in an area of eastern Japan on Honshu Island (it is no. 10 in Table 2 and Fig. 3) affected the behavior of seismic processes, including that in Kamchatka. The seismic quiescence of 2010 in Kamchatka was followed, practically simultaneously by the giant earthquake mentioned above, by seismicity increases nos. 9.1, 9.2, and 9.3 (see Figs. 2 and 3, Table 2). One of these increases (9.3) occurred on March 4 through 9, 2011 in the most dangerous area close to Petropavlovsk-Kamchatskii, viz., the outer boundary of segment 12.

We now discuss the most important features of the 2012-2013 seismicity at the Kuril-Kamchatka arc.

The deep-focus Sea-of-Okhotsk earthquake of August 14, $2012(\mathrm{M}=7.7, \mathrm{H}=583 \mathrm{~km})$ was preceded, 4 months before the event, by seismicity increases and M 5.6-6.0 earthquakes in the seismic gaps above its rupture zone, along the Kuril part of the arc, in segments 1, 6, 7, and 9: events nos. 13-16 in Table 2 and in Figs. 2 and 3.

The Urup earthquake sequence in July 2012 through August 2013 (events nos. 15 and 24, segment 6, see Table 2, Figs, 2 and 3) lasted a long time (approximately a year) and was complex in character: its terminal phase involved a north-northwestward displacement of the initial seismicity increase, deeper toward the rupture zone of the May 24, 2013 Sea-ofOkhotsk earthquake. The largest event that controlled this displacement was the magnitude 7.2 earthquake of April 19, 2013 (no. 24, see Table 2, Figs. 2 and 3), which occurred at an intermediate depth $(\mathrm{H}=118 \mathrm{~km})$. It signaled a stress increase in the Benioff zone before the Sea-of-Okhotsk earthquake of May 24, 2013.

The hypocenters of earthquakes nos. 18, 19, 2123 , and 25 were seen to be moving at depths of less than $200 \mathrm{~km}$ from segment 6 toward segments 11 and 12 (the projection of the great Sea-of-Okhotsk earthquake of May 24, 2013) during the period between the large deep-focus earthquake of August 14, 2012 (M = $7.7, \mathrm{H}=583 \mathrm{~km}$ ) and the Sea-of-Okhotsk earthquake of May 24, 2013, M 8.3, no. 26. This phenomenon shows that the precursory process of the great earthquake was also occurring in the region of shallower earthquakes at the most active part of the Kuril-Kamchatka earthquake-generating zone.

Summing up, we can say that the 2012-2013 period saw a precursory migration of seismicity (including rapid events of this kind lasting only a few days) consisting of shallow earthquakes in the Kuril-Kamchatka earthquake-generating zone and of intermediate earthquakes at depths of $80-200 \mathrm{~km}$. The migration tended toward the projections of future deepfocus $M \geq 7.7$ earthquakes onto the upper part of the arc. These occurrences are in agreement with a model that assumes interrelationships between earthquakes throughout the entire depth range of plunging plates (Mogi, 1985; Yunga et al., 2011; Rogozhin et al., 2011).

After the Sea-of-Okhotsk earthquake of May 24, 2013, $M_{\mathrm{W}} 8.3$, no. 26, the 2014-2016 earthquakes at intermediate depths (80-200 km) nos. 33, 34, and 39 $\left(\mathrm{M}_{\mathrm{W}}=7.2\right)$ concentrated in the Kamchatka segment of the Kuril-Kamchatka arc around segment 12b, near the most dangerous seismic gap in the region (see Figs. 1, 2, 3).

These earthquakes included the remarkable Zhupanov event with $\mathrm{M}_{\mathrm{W}}=7.2$, which occurred at a depth of $185 \mathrm{~km}$ on January 30, 2016 in the area of Zhupanov Volcano (no. 39) (Chebrov et al., 2016) (see Fig. 2).

Rare large earthquakes at intermediate depths (80$200 \mathrm{~km}$ ) can pose hazard in their epicentral areas. The magnitude 7.3 earthquake of November 24, 1971, which occurred at a depth of $100 \mathrm{~km}$, produced shaking of intensity VII at Petropavlovsk-Kamchatskii (Sil'nye kamchatskie ..., 1975). It is important that the probability of earthquakes at depths of $80-200 \mathrm{~km}$ is an order of magnitude below that at depths shallower than $80 \mathrm{~km}$ in the most active part of the Kuril-Kamchatka earthquake-generating zone, while their intensity of shaking decays rapidly with increasing depth of occurrence.

Following the great, magnitude 8.3, deep-focus Sea-of-Okhotsk earthquake of May 24, 2013, the seismicity in the Kamchatka part of the Kuril-Kamchatka earthquake-generating zone increased mostly in the region of earthquakes at depths of 90-185 km along the extension of the earthquake-generating zone of the arc toward the deep-sea trench away from the rupture zone of the Sea-of-Okhotsk earthquake, segments 11 and 12 in Figs. 2 and 3.

\section{Supplements to the Long-Term Earthquake Forecast for the Kuril-Kamchatka Arc for the April 2016 through March 2021 Period}

The projection of the deep rupture zone of the May 24, 2013 Sea-of-Okhotsk earthquake onto the zone of shallow earthquakes at the arc contains a long seismic gap $(350 \mathrm{~km})$ that poses the highest hazard at present. It is likely that the rupture of a great $\mathrm{M}>8.3$ earthquake $500 \mathrm{~km}$ long can involve segment 10 , in addition to segments 11 and 12. The edges of segment 10 had 
remarkable swarms of earthquakes nos. 4 and 21 (2008 and 2013) and nos. 13, 16, 18, and 19 (2012) (see Table 2 and Fig. 2). The southern tip of the mainshock rupture of a future great Kamchatka earthquake may be situated in these places.

The evolution of the 2008-2016 seismicity shows that the earthquake hazard emanating from segments 11, 12, as well as segment 10, between the Avacha Bay and the North Kuril Islands, may exceed the level as determined for these segments using the well-tested LTEP techniques, Section 1.

The Avacha Bay area, segment 12, as well as the entire Kamchatka part of the arc, segments 11 through 15, show the highest activity at present (see Fig. 3). This is due to a unidirectional evolution of seismotectonic processes at the arc following the deep-focus Sea-of-Okhotsk earthquake of May 24, 2013.

The Kuril part of the arc showed a significant decrease in seismicity in segments 6 through 8 following the May 24, 2013 Sea-of-Okhotsk earthquake along the long Middle-Kuril seismic gap, which is the second by hazard at the arc (see Figs. 1 and 2, Table 1). According to the LTEP method, this may entail some decrease in the hazard posed by these segments.

One notes a seismicity increase in the region of shallow South Kuril earthquakes in segments 2 through 5 during 2011 through 2016 (see Figs. 1 through 3); note that these segments are not seismic gaps. The time-dependent display in Fig. 3 reveals that the increase occurred at the time of the giant Tohoku earthquake of March 11, 2011. One can thus say that this earthquake exerted a powerful and long-continued influence on the South Kuril segments of the earthquake-generating zone that are not seismic gaps. This may signify a considerable stress rearrangement in a region that occupies the beginning of the prediction band, segments 2 through 5, and a possible long-term increase in the probability of a great earthquake in that area compared with the values listed in Section 1.

An enormous amount of seismic energy has been stored in the Kamchatka part of the earthquake-generating zone, especially in the seismic gap of segments 11 and 12 (see Figs. 1, 2). This amount would be proper for a magnitude 8-9 earthquake (Fedotov et al., 2011). These results form a basis for an independent inference that the highest earthquake hazard will emanate from these segments.

The evolution of the Kuril-Kamchatka seismicity in 2008 through 2016 before, during, and after the deep-focus Sea-of-Okhotsk earthquakes of July 5, 2008, August 14, 2012, and May 24, 2013 (the respective magnitudes were 7.7, 7.7, and 8.3) was a powerful, rare, and very interesting process. The present study presents a brief review of events during that process between 2013 and 2016. The time-distance display of the seismic process at the arc during those years is shown in Fig. 3. It can be seen that the seismicity along the arc was different in its three parts. It was the high- est in the Kamchatka part with the segments posing the greatest hazard, 11 and 12, being in the area of Petropavlovsk-Kamchatskii.

The seismicity of the South Kuril part has increased, but does not seem to provide evidence of a high hazard, since segments 2 through 5 do not contain seismic gaps that are in phase III, the terminal phase of the seismic cycle.

The lowest intensity of seismic activity is observed on the Middle Kuril Islands in the area of the MiddleKuril (Simushir) earthquakes of November 15, 2006 with $\mathrm{M}_{\mathrm{W}}=8.2$ and of January 13, 2007 with $\mathrm{M}_{\mathrm{W}}=8.1$, segment 7 (see Figs. 1, 2).

The information on seismicity behavior and updates to the long-term earthquake forecast for the Kuril-Kamchatka arc (LTEP) reviewed in Section 2, as well as evidence from other earthquake prediction methods, will be considered during further improvements on the LTEP method, and when developing forecasts for the next time intervals.

Below we present basic information on practical uses of the LTEP method.

\section{CONCLUSIONS: FORECASTS AND PRACTICAL APPLICATIONS OF THE LTEP METHOD IN 1985 THROUGH 2016}

Earthquake protection for Kamchatka and the Kuril Islands, in the region where the level of seismicity and earthquake hazard is the highest in Russia, is a task of national importance. It is this circumstance which makes the work conducted by the IV\&S FEB RAS on the long-term earthquake prediction method one of the more important projects of the Russian Academy of Sciences in the Russian Far East.

The previous long-term earthquake forecasts derived by the LTEP method used here, the identification of the more dangerous locations in the region, and warnings as to urgent necessity of timely measures for seismic protection and seismic retrofitting, have furnished a basis for decrees and orders of the USSR Council of Ministers (1986 and 1989), of the Council of Ministers of the Russian Federation (then part of the USSR), and of the Government of the Russian Federation (1995 and 2001), as well as several government decisions in 2002-2016 on the earthquake preparedness of Kamchatka Region (Fedotov, 2005; Fedotov et al., 2008; Fedotov and Solomatin, 2015; among others).

According to the LTEP forecast for the April 2016 through March 2021 period, the highest seismic hazard for $M \geq 7.7$ earthquakes remains as before in the area of Petropavlovsk-Kamchatskii. Here, in the Avacha Bay and off southern Kamchatka, there is the largest seismic gap $350 \mathrm{~km}$ long of the entire Kuril-Kamchatka arc that is capable of generating an $\mathrm{M} \geq 8.3$ earthquake. Overall, the probability of shaking inten- 
sities of VII-IX at Petropavlovsk-Kamchatskii reached $43.7 \%$ during those years.

The probability of a great earthquake on the coast of the Avacha Bay producing shaking of intensity IX at Petropavlovsk-Kamchatskii with a corresponding catastrophic impact is $12.8 \%$ as estimated here. The probability of $\mathrm{M} \geq 7.7$ earthquakes occurring in the area under discussion is 3 to 4 times the average value for the earthquake-generating zone of the arc. The probability of an $M \geq 7.7$ earthquake occurring in the Avacha Bay or off southern Kamchatka and producing shaking of intensity VIII-IX at Petropavlovsk-Kamchatskii is estimated as $30.9 \%$.

The segments of the second highest hazard along the Kuril-Kamchatka arc for the period April 2016 through March 2021 are on the Kuril Islands. One of these is southwest of the rupture zone of the $M_{\mathrm{W}} 8.2$ Middle-Kuril (Simushir) earthquake of November 15, 2006, and the other two segments are northeast of it. The combined probability of $\mathrm{M} \geq 7.7$ earthquakes is $29.7 \%$ for these segments.

Some additional information was obtained by inspection of isolines of $A_{10}$, earthquake swarms, and other seismicity features that were observed at the Kuril-Kamchatka arc during 2013 through 2016 after the great deep-focus earthquakes beneath the Sea of Okhotsk in 2008 through 2013. These and other data confirm the previous inference that the forecast of the highest seismic hazard is for the area of PetropavlovskKamchatskii, probably greater than the value derived by the basic method.

All these data show that the necessity of urgent measures for seismic safety, enhancement of earthquake resistance of residential buildings and of the main lifeline facilities in Kamchatka Krai remains today. Seismic retrofitting and new earthquake-resistant construction in Petropavlovsk-Kamchatskii should be continued and expanded in 2016 and later.

The work using this long-term prediction method should be continued, together with studies on the behavior and patterns of seismicity at the Kuril-Kamchatka arc, the development and improvement of the LTEP method, its application together with other earthquake prediction techniques, as well as comparative research on the nature and mechanism of seismic activity in the Kuril-Kamchatka region and in adjoining regions.

It is necessary to intensify observations of seismicity in the area of Petropavlovsk-Kamchatskii in the Avacha Bay, which is the most likely location of the rupture zone for the next intensity IX earthquake in the region. Overall, southern Kamchatka and the Avacha Bay are the top-priority locations in Russia to require further work in long-term earthquake prediction, other seismic prediction techniques, and in the assessment of seismic risk.

The long-term earthquake forecasts that we have derived are at the same time forecasts of dangerous tsunamis for the shores of Kamchatka and the Kuril Islands. The method can also be applied to other regions worldwide with similar structures, geodynamics, and seismicity.

\section{The Practical Significance of LTEP Research during the Previous Period and Later Developments}

Since 1985 the long-term earthquake forecasts for the Kuril-Kamchatka arc have been the basis for governmental retrofitting measures in the region. These forecasts furnished a basis for over ten decrees and decisions of the USSR Council of Ministers, the Council of Ministers of the Russian Federation (then part of the USSR), as well as of the Government of the present Russian Federation in 1986-2015 to take earthquake preparedness measures for Kamchatka Region (Fedotov, 2005; Fedotov and Solomatin, 2015; among others).

The forecasts and warnings issued so far served as a basis for retrofitting 144 buildings in PetropavlovskKamchatskii in 1990-2004 that were insufficiently (by intensity grades 2-3) earthquake-resistant. The 20000 residents of these houses have now been supplied with protection; this is approximately one-tenth of the total city population.

In 2009 the Government of the Russian Federation approved the Federal Target Program entitled Enhancement of Stability for Residential Houses, Main Lifeline Facilities in Seismic Regions of the Russian Federation for 2009-2018. The July 30, 2009 Decree no. 615 allotted 8.1 billion rubles for 20092013 to do the work.

In 2013 the Government of Kamchatka Krai adopted a decree on the target program Enhancing the Stability of Residential Houses and Main Lifelines in Kamchatka Krai for 2013-2015 (no. 72-P as of February 25, 2013). An amount of 4.3 billion rubles was allocated for its execution. The expected prevented loss is 43 billion rubles.

The above described measures based on the scientific basis of long-term earthquake forecasts, have prevented a loss of over 400 billion rubles; $75 \%$ of all residential houses in Petropavlovsk-Kamchatskii by now have the necessary strength to withstand earthquakes. However, a great earthquake in the area of Petropavlovsk-Kamchatskii still poses the threat of becoming the worst natural disaster in Russia. Under these conditions, the work of retrofitting and earthquake-resistant construction in Petropavlovsk-Kamchatskii must be expanded as much as possible in the future.

The work in long-term earthquake prediction aiming at great earthquakes at the Kuril-Kamchatka arc have served during three decades (1985-2016) to substantiate measures of seismic safety in Kamchatka Krai and is among the most important projects undertaken by the Russian Academy of Sciences in the Far East of Russia. 
The above long-term forecast of $\mathrm{M} \geq 7.7$ earthquakes for the Kuril-Kamchatka arc for the period April 2016 through March 2021 can be used exactly as was done with the preceding forecasts in 1985-2015 to substantiate governmental measures for earthquake protection and seismic retrofitting.

During the preceding years Academician Yu.S. Osipov, President of the RAS; Academician N.P. Laverov, vice-president of the RAS; V.I. Sergienko, Chairman of the Far East Branch of the RAS; A.O. Gliko, Academician-Secretary of the Geosciences Section; and V.I. Ilyukhin, Governor of Kamchatka Krai, all were invariably in support of the relevant research and proposed necessary measures for the prevention of catastrophic damage and losses.

\section{ACKNOWLEDGMENTS}

This work was conducted for the FEB RAS Far East Program of Basic Research, project no. 15-I-2035 Long-Term Earthquake Prediction for the KurilKamchatka Arc: Continued Prediction Work, Substantiation of Measures to Enhance Earthquake Resistance, the Development of the Method, and Applications to Other Regions Worldwide.

\section{REFERENCES}

Chebrov, V.N., Vikulina, S.A., Droznina, S.Ya., et al., Large earthquakes in Kamchatka in 2013, in Problemy kompleksnogo geofizicheskogo monitoringa Dal'nego Vostoka Rossii (Problems in the Multidisciplinary Geophysical Monitoring of the Russian Far East), Abstracts of reports, The Fourth Conf., September 29 through October 5, 2013, Petropavlovsk-Kamchatskii, 2013, pp. 132-136. (http://emsd.ru/conf2013lib/pdf/seism/ Chebrov_etc.pdf).

Chebrov, V.N., Kugaenko, Yu.A., Abubakirov, I.R., Droznina, S.Ya., et al., The Zhupanovo earthquake of January 30, 2016 with $\mathrm{K}_{\mathrm{S}}=15.7, \mathrm{M}_{\mathrm{W}}=7.2, I=6$ (Kamchatka), Vestnik KRAUNTs, Nauki o Zemle, 2016, no. 1, issue 29, pp. 5-16.

Fedotov, S.A., On patterns observed in the locations of large earthquakes in Kamchatka, the Kuril Islands, and northeast Japan, Trudy IFZ AN SSSR, 1965, no. 36, pp. 66-93.

Fedotov, S.A., On the seismic cycle, possibilities of quantitative seismic zonation, and long-term earthquake prediction, in Seismicheskoe raionirovanie SSSR (Seismic Zonation of the USSR), Moscow: Nauka, 1968, pp. $121-150$.

Fedotov, S.A. Energeticheskaya klassifikatsiya Kurilo-Kamchatskikh zemletryasenii $i$ problema magnitud (The Energy Classification of Earthquakes and the Magnitude Problem), Moscow: Nauka, 1972.

Fedotov, S.A., Dolgosrochnyi seismicheskii prognoz dlya Kurilo-Kamchatskoi dugi (Long-term Earthquake Prediction for the Kuril-Kamchatka Arc), Moscow: Nauka, 2005.

Fedotov, S.A., Chernyshev, S.D., Chernysheva, G.V., and Vikulin, A.V., Refining the boundaries of the $M \geq 73 / 4$ earthquake rupture areas, the properties of the seismic cycle, and the long-term earthquake forecast for the Kuril-Kamchatka arc, Vulkanol. Seismol., 1980, no. 6, pp. 52-67.

Fedotov, S.A., Solomatin, A.V., and Chernyshev, S.D., Long-term earthquake forecast for the Kuril-Kamchatka arc for 2004-2008 and a retrospective forecast of the $\mathrm{M}=8.1$ September 25, 2003, Hokkaido earthquake, Vulkanol. Seismol., 2004, no. 5, pp. 3-32.

Fedotov, S.A., Solomatin, A.V., and Chernyshev, S.D., A long-term earthquake forecast for the Kuril-Kamchatka island arc for the period 2006-2011 and a successful forecast of the $\mathrm{M}_{\mathrm{S}}=8.2$ Middle Kuril earthquake of November 15, 2006, J. Volcanol. Seismol., 2007, vol. 1 , no. 3, pp. 143-163.

Fedotov, S.A., Solomatin, A.V., and Chernyshev, S.D., Aftershocks and the rupture zone of the $\mathrm{M}_{\mathrm{S}}=8.2$, November 15, 2006 Middle Kuril Is. earthquake and a long-term earthquake forecast for the Kuril-Kamchatka arc for the period from April 2008 to March 2013, J. Volcanol. Seismol., 2008, vol. 2, no. 6, pp. 375394.

Fedotov, S.A., Solomatin, A.V., and Chernyshev, S.D., A long-term earthquake forecast for the Kuril-Kamchatka arc for the period from September 2010 to August 2015 and the reliability of previous forecasts, as well as their applications, J. Volcanol. Seismol., 2011, vol. 5, no. 2, pp. 75-99.

Fedotov, S.A., Solomatin, A.V., and Chernyshev, S.D., A long-term earthquake forecast for the Kuril-Kamchatka arc for the period from September 2011 to August 2016. The likely location, time, and evolution of the next great earthquake with $\mathrm{M} \geq 7.7$ in Kamchatka, J. Volcanol. Seismol., 2012, vol. 6, no. 2, pp. 75-99.

Fedotov, S.A. and Solomatin, A.V., The long-term earthquake forecast for the Kuril-Kamchatka island arc for the September 2013 to August 2018 period; The seismicity of the arc during preceding deep-focus earthquakes in the Sea of Okhotsk (in 2008, 2012, and 2013 at $\mathbf{M}=7.7$, 7.7, and 8.3), J. Volcanol. Seismol., 2015, vol. 9, no. 2, pp. $65-80$.

Mogi, K., Earthquake Prediction, Tokyo, New York, London: Academic Press, 1985.

Riznichenko, Yu.V., Seismic activity and intensity recurrence, in Seismicheskoe raionirovanie SSSR (The Seismic Zoning of the USSR), Moscow: Nauka, 1968, pp. 112-120.

Rogozhin, E.A., Ioganson, L.I., and Zav'yalov, A.D., Potentsial'nye seismicheskie ochagi $i$ seismologicheskie predvestniki zemletryasenii-Osnova real'nogo prognoza zemletrasenii: $k$ 65letiyu E.A. Rogozhina (Potential Seismic Rupture Zones and Seismological Precursors of Earthquakes: A Basis for Real Earthquake PredictionFor the 65th Anniversary of E.A. Rogozhin), ISBN: 978-5-904393-06-9, Moscow: Svetoch Plyus, 2011. (http://www.rfbr.ru/rffi/ru/books/o_1779655).

Safonov, D.A., Konovalov, A.V., and Zlobin, T.K., The Urup earthquake sequence of 2012-2013, J. Volcanol. Seismol., 2015, vol. 9, no. 6, pp. 402-411.

Saltykov, V.A. and Kravchenko, N.M., Seismicity parameters for Kamchatka in 2007-2008, in Vtoraya regional'naya nauchno-tekhnicheskaya konferentsiya "Problemy kompleksnogo geofizicheskogo monitoring 
Dal'nego Vostoka Rossii" (Second Science Conference "Problems in Multidisciplinary Monitoring of the Russian Far East"), October 11-17, 2009, PetropavlovskKamchatskii, Abstracts of reports, PetropavlovskKamchatskii: GS RAN, 2009, pp. 9.

Saltykov, V.A. and Kravchenko, N.M., Seismicity parameters for Kamchatka in 2009-2010, in Tret'ya regional'naya nauchno-tekhnicheskaya konferentsiya "Problemy kompleksnogo geofizicheskogo monitoring Dal'nego Vostoka Rossii" (Third Science Conference "Problems in Multidisciplinary Monitoring of the Russian Far East”), October 9-15, 2011, PetropavlovskKamchatskii, Abstracts of reports, PetropavlovskKamchatskii: GS RAN, 2011, pp. 134-138. http:// www.emsd.ru/files/konf111009/pdf/sb/Sekciya_Monitoring/Saltyikow.pdf.

Saltykov, V.A., Kravchenko, N.M., Volovich, O.G., et al., Seismicity parameters for Kamchatka in 2011-2012, in Chetvertaya regional'naya nauchno-tekhnicheskaya konferentsiya "Problemy kompleksnogo geofizicheskogo monitoring Dal'nego Vostoka Rossii” (Fourth Science Conference "Problems in Multidisciplinary Monitoring of the Russian Far East"), September 29 through October 5, 2013, Petropavlovsk-Kamchatskii, a collection of papers, Petropavlovsk-Kamchatskii: GS RAN, 2013, pp. 190-194. http://www.emsd.ru/conf2013lib/pdf/ seism/Saltikov_etc.pdf.

Sil'nye kamchatskie zemletryaseniya 1971 goda (The Large Kamchatka Earthquakes of 1971), Fedotov, S.A., Editor-in-Chief, Vladivostok: Institut Vulkanologii DVNTs AN SSSR, 1975.

Sil'nye kamchatskie zemletryaseniya 2013 goda (The Large Kamchatka Earthquakes of 2013), Chebrov, V.N., Ed., Petropavlovsk-Kamchatskii: Novaya Kniga, 2014.

Sobolev, G.A. and Ponomarev, A.V., Fizika zemletryasenii $i$ predvestniki (Earthquake Physics and Precursors), Moscow: Nauka, 2003.

Yunga, S.L., Rogozhin, E.A., and Rodina, S.N., Analysis of deep focal mechanisms and revealing of possible large earthquake zones in the Kuril-Okhotsk region, Seismic Instruments, 2012, vol. 48, no. 3, pp. 226-234.

Translated by A. Petrosyan 